
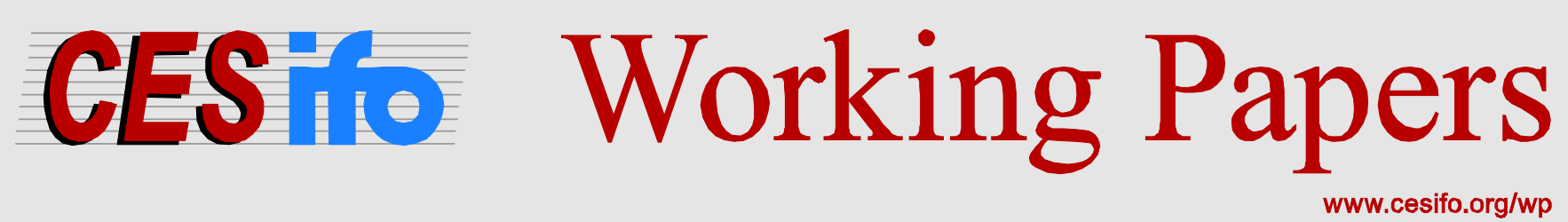

\title{
An Economist's Perspective on Student Loans in the United States
}

\author{
Susan Dynarski
}

CESIFO WORKING PAPER NO. 5579

CATEGORY 5: ECONOMICS OF EDUCATION

OCTOBER 2015

An electronic version of the paper may be downloaded

- from the SSRN website:

- from the RePEc website:

WWw.SSRN.com

www.RePEc.org

- from the CESifo website:

www.CESifo-group.org/wp 


\title{
An Economist's Perspective on Student Loans in the United States
}

\begin{abstract}
In this paper, I provide an economic perspective on policy issues related to student debt in the United States. I lay out the economic rationale for government provision of student loans, summarize time trends in student borrowing, describe the US loan market, then turn to topics central to the policy discussion of student loans: whether there is a student debt crisis, the costs and benefits of interest subsidies, and the suitability of an income-based repayment system for student loans. I close with a discussion of the gaps in the data required to fully analyze and steer student-loan policy.
\end{abstract}

Keywords: student debt, student loans, subsidies.

\author{
Susan Dynarski \\ Education Policy Initiative \\ Gerald R. Ford School of Public Policy \\ University of Michigan \\ 735 South State Street, Suite 5100 \\ USA - Ann Arbor, Michigan 48109-3091 \\ dynarski@umich.edu
}

September 2014

Comments welcome. This paper was prepared for the 2014 East-West Center/Korean Development Institute Conference on a New Direction in Human Capital Policy. This research was partially supported by a grant from the Spencer Foundation. All views and errors are my own. 


\section{Introduction}

Forty million people in the United States hold student debt totaling \$1 trillion. While other forms of consumer credit declined during the Great Recession (see Figure 1), student debt continued to rise. As a result, student loans are now, after mortgages, the largest source of household debt, outstripping credit cards and auto loans.

\section{Figure 1: Trends in Non-Mortgage Consumer Debt}

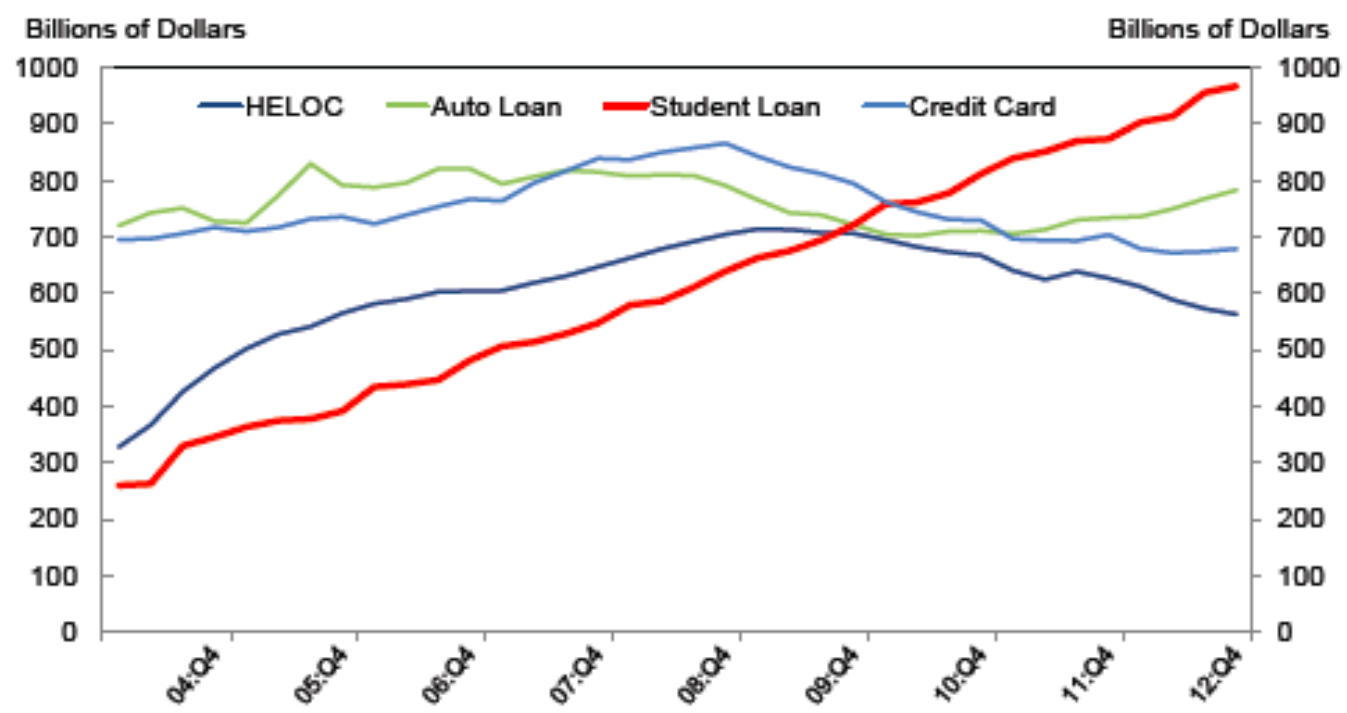

Source: Lee (2013), based on data from the Federal Reserve Bank of New York. "HELOC” indicates home-equity lines of credit. 
Defaults on student debt also rose during the Great Recession. ${ }^{1}$ Seven million student borrowers are now in default, with more behind on their payments. ${ }^{2}$ Proposed policy responses have included reductions in interest rates, forgiveness of student debt, more flexible repayment plans and increased regulation of college prices. In the latest effort to respond to widespread policy concern that there is a student debt crisis, President Obama signed in June 2014 an executive order expanding eligibility for the Pay As You Earn program, which offers reduced payments to borrowers in financial distress.

In this paper, I provide an economic perspective on policy issues related to student debt in the United States. I begin by laying out the economic rationale for government provision of student loans. I show time trends in student borrowing and describe the structure of the US loan market, which is a joint venture of the public and private sectors. I then turn to three topics that are central to the policy discussion of student loans: whether there is a student debt crisis, the costs and benefits of interest subsidies, and the suitability of an income-based repayment system for the US. I close with a discussion of the gaps in the data required to fully analyze and steer student-loan policy.

To preview, I argue that there is no debt crisis: student debt levels are not large relative to the estimated payoff to a college education in the US. Rather, there is a repayment crisis, with

\footnotetext{
${ }^{1}$ The US Department of Education, which administers the federal loan programs, defines default. This definition has varied over time, hindering the creation of a consistent measure of borrower distress. At present, default indicates a borrower has not made a payment in 270 days; in the past, this window has been narrower.

${ }^{2}$ There were 6.5 million borrowers in default as of the third quarter of 2013. See http://studentaid.ed.gov/sites/default/files/fsawg/datacenter/library/PortfoliobyLoanStatus.xls.
} 
student loans paid when borrowers’ earnings are lowest and most variable (Dynarski and Kreisman, 2013). As a result, there is a mismatch in the timing of the arrival of the benefits of college and its costs. Ironically, this mismatch is the very motivation for providing student loans in the first place.

One solution is an income-based-repayment structure for student loans, with a longer window for repayment than the ten years that is currently the standard. While there exist incomebased repayment options within the current system, few borrowers take them up. The administrative barriers to accessing these options are considerable, which may explain the low take-up rate. Further, the existing options do not adjust loan payments quickly enough to respond to the high-frequency shocks that characterize young people’s earnings, especially during a recession.

A well-structured repayment program would insure borrowers against both micro and macro shocks. With an interest rate that appropriately accounts for the government's borrowing and administrative costs, as well as default risk, this program could be self-sustaining. Designing such a program requires detailed data on individual earnings and borrowing, which are currently unavailable to researchers within and outside the government. If loan policy is to be firmly grounded in research, this gap in the data needs to be closed.

\section{The Economic Rationale for Government Loans to Students}

Education is an investment. Like all investments, education creates costs in the present but delivers benefits in the future. While students are in in school, expenses include both direct costs (tuition, books) and opportunity costs. Future benefits include increased earnings, improved health and longer life. To pay the current costs of their education, students need liquidity. In a 
business deal, a borrower would put up collateral in order to fund a potentially profitable investment. The collateral would typically include any capital goods used in the fledging enterprise, such as a building or machinery. Similarly, homeowners put up their home as collateral when they take out a mortgage.

Students cannot put themselves up for collateral: they cannot contractually commit to hand over their future labor to a lender in exchange for upfront cash, because indentured servitude is illegal. This is a market failure—-there are good investments to be made, but private lenders cannot or are reluctant to make these loans, just as they are reluctant to make (and therefore demand higher interest rates for) other unsecured loans, such as credit cards. This market failure explains why governments play an important role in lending for education. While there have been occasional efforts to offer loans securitized by human capital (e.g., My Rich Uncle), none has moved beyond a small niche market. Indeed, the public sector of most developed countries and many developing countries provide loans to students. ${ }^{3}$

Given their prevalence, there is remarkably little compelling evidence of the effect of student loans on educational investments. ${ }^{4}$ Students choose to borrow, so estimating the effect of loans on outcomes is challenging: those who borrow likely differ from non-borrowers in ways that will bias naive comparisons of their educational attainment. A randomized trial would solve

\footnotetext{
${ }^{3}$ In part, this is because it is very difficult for private parties to place a lien on (or confirm) individual earnings. By contrast, governments, through the income tax system, have the ability to both measure and collect from income.

${ }^{4}$ See Dynarski and Scott-Clayton (2013) for a review of this evidence.
} 
the selection problem, but there has been no experiment in which access to student loans is randomly manipulated. ${ }^{5}$

The best observational evidence comes from South Africa and Chile (Solis, 2012; Gurgand, et al, 2011). In these countries, students are offered loans only if they have a minimum credit score (South Africa) or test score (Chile). The papers that analyze these loan programs compare the college attendance of students right above and below these cutoffs, capturing the causal impact of loan availability. This research approach is referred to as "regressiondiscontinuity” design. In a well-designed regression-discontinuity study, that it is essentially random that someone ends up right above or right below the eligibility cutoff. A comparison of these two groups therefore yields a causal estimate of the effect of program eligibility.

In Chile, right below the eligibility cutoff, 20 percent of students go to college. Right above, the figure is 40 percent. The difference - 20 percentage points — is the estimated causal effect of loan availability on college attendance for these students. The South African study reaches a similar conclusion. Right below the credit-score cutoff, 50 percent of students go to college, compared with 70 percent right above. Again, the estimated effect is a 20-percentagepoint increase in college attendance. These are large effects, indicating that student loans make college possible for many students, at least in these two countries. While we would prefer to have evidence from the United States, these studies currently constitute the best available evidence on the causal impact of student loans on educational attainment.

\section{Trends in Student Borrowing}

\footnotetext{
${ }^{5}$ Field (2009) studies an experiment in which loan-repayment terms were randomly varied at a law school.
} 
As noted earlier, the stock of outstanding student debt now exceeds $\$ 1$ trillion. The flow of debt has also increased, with annual borrowing doubling between 2001 and 2011 (from \$56 billion to $\$ 113$ billion, in constant 2011 dollars). ${ }^{6}$ Borrowing has increased, in part, because there are more students: college enrollment rose 32 percent in the decade between 2001 and 2011.

Figure 2: Aid per Full-Time-Equivalent Student

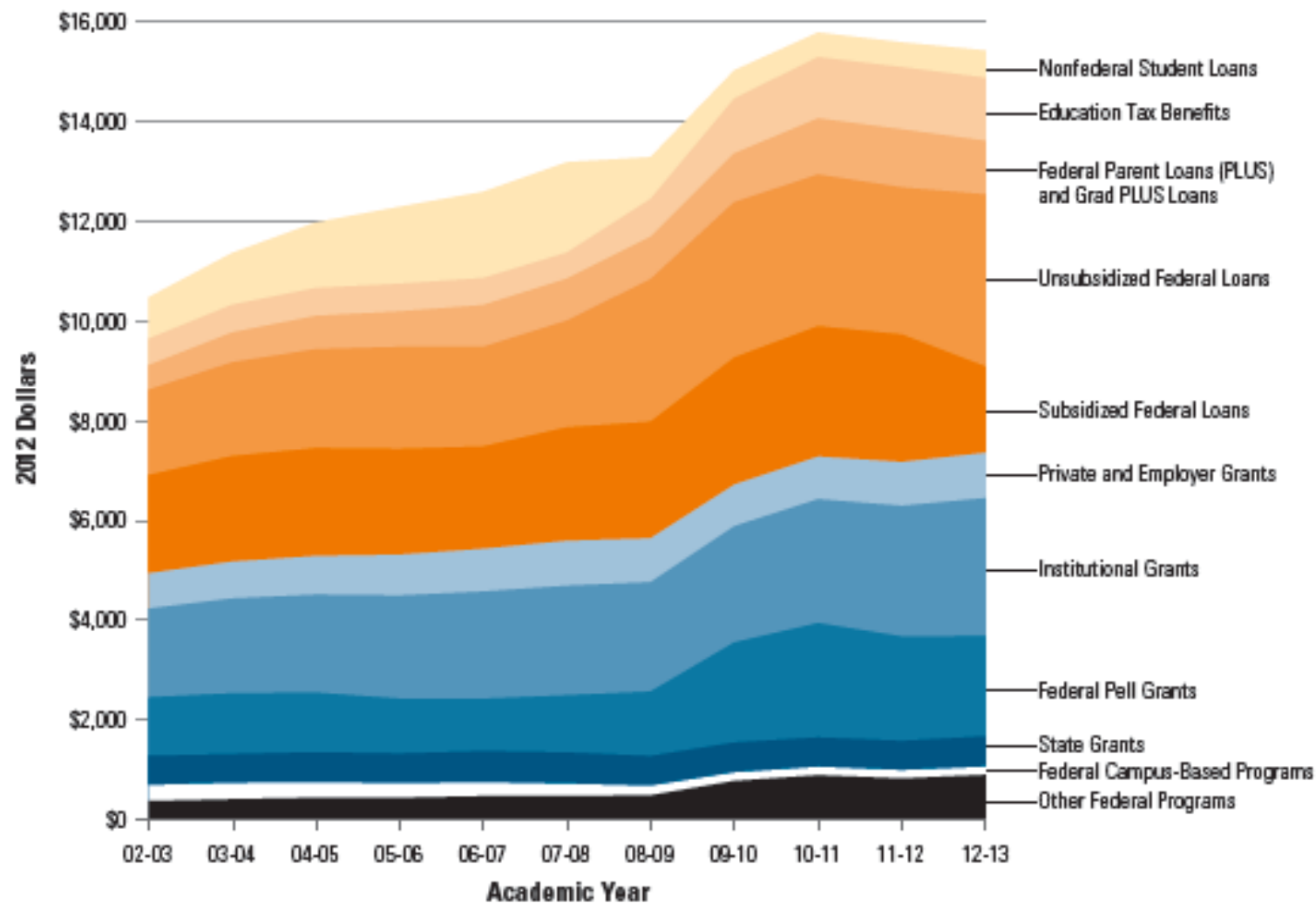

Source: College Board (2013), Figure 1.

${ }^{6}$ See Figure 6 in College Board (2012). 
But as the number of students increased, so too did annual borrowing per student, rising from $\$ 3,500$ to $\$ 5,400$, an increase of 54 percent. ${ }^{7}$ This per-student increase in borrowing can be explained by one or both of two factors: an increase in the share of students taking out loans and/or an increase in the size of the loans borrowers take out. Both of these factors appear to be at work over the past decade. As discussed later in the paper, federal Stafford loans are the largest loan program, accounting for 75 percent of student-loan volume (labeled as unsubsidized and subsidized federal loans in Figure 2). In 200134 percent of undergraduates took out a Stafford loan; by 2011 that number had risen to 50 percent. ${ }^{8}$ The average loan taken out by each borrower went up by only 8 percent, by contrast—from \$7,600 to \$8,200, in constant 2011 dollars. The increases in the Stafford program, at least, are therefore on the extensive rather than the intensive margin.

While we know that students now borrow more, the reasons are not well understood. Rising college costs are a natural suspect. The sticker price of college has risen for years, but so too has aid for college (see Figure 3). At public colleges, where 80 percent of students are enrolled, the sticker price of college increased by \$3,450 in real terms from 2001 to 2011. But after netting out increases in grants and tax credits, the net price of college rose by just \$1,160.

\footnotetext{
7 Total fall enrollment (undergraduate and graduate) rose from 15.9 to 21.0 million between 2001 and 2011. See Table 221 in US Department of Education (2012).

${ }^{8}$ Besides Stafford, most other loans are also federal; just 7 percent of student loan volume was from private sources in 2011-12. PLUS loans to parents are the second-largest source of student borrowing (10 percent of volume), followed by PLUS loans to graduate students (6 percent). See Figure 6 in College Board (2012). The private and parental PLUS loans require a credit check or cosigner and so, as discussed earlier, are not classic student loans, which are secured only by the future earnings of the borrower.
} 
At private schools, which frequently offer grants to students, net prices rose even less, by $\$ 320$. These increases in net price cannot fully explain the \$1,900 increase in average borrowing.

\section{Figure 3: Trends in the Sticker Price and Net Price of College}

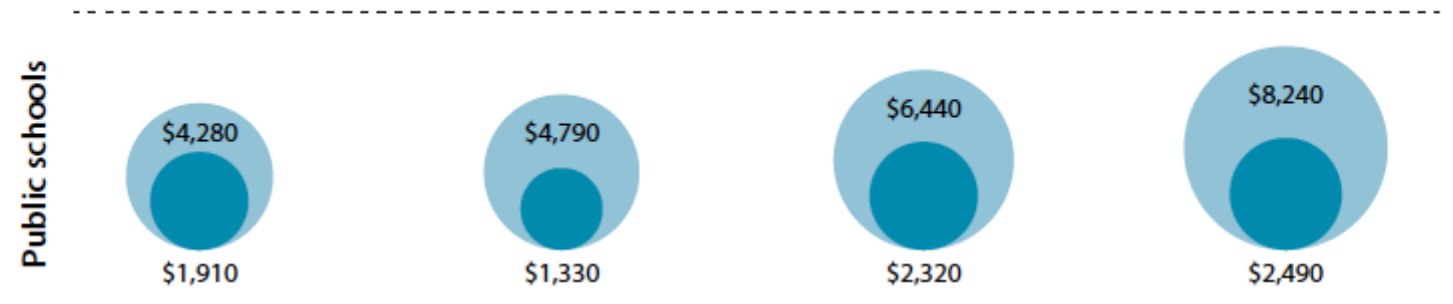

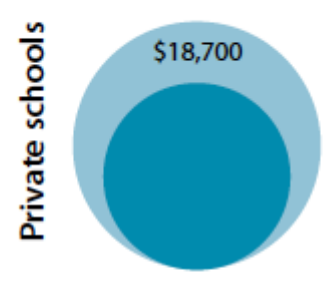

$\$ 10,630$

1996-97

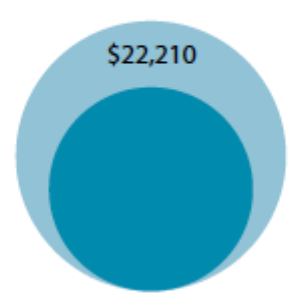

$\$ 12,650$

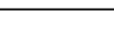

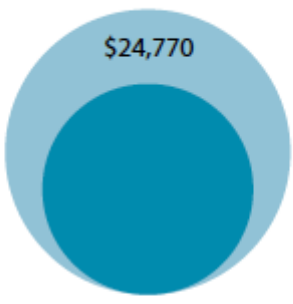

$\$ 13,520$

2006-07

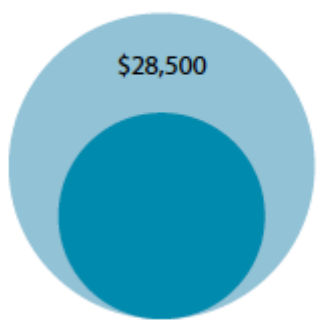

$\$ 12,970$

2011-12

Sticker price

Net price

Source: Based on data in National Postsecondary Student Aid Survey, as analyzed by College Board (2012).

The family income distribution has become much more unequal over the past several decades, with incomes dropping among the lowest-earning households, stagnating in the middle, and rising only at the very top (Piketty and Saez, 2003). For the majority of families, flat college costs represent a mounting share of family income. These shifts in the income distribution may explain at least part of the increasing reliance on loans to cover college costs. 
Despite these increases in borrowing, the vast majority of students still borrow moderate amounts. As discussed below, in 2009, 69 percent of undergraduates had borrowed $\$ 10,000$ or less. Only two percent borrowed more than $\$ 50,000$.

\section{Students Loans in the US are A Public-Private Venture}

The modern student loan program dates to 1965, when the Guaranteed Student Loan, now known as the Stafford Loan, was initiated. From the start, federal student loans were a joint venture of the public and private sectors. Private lenders provided capital, took applications, disbursed loans and collected payments. The federal government defined eligibility for loans, paid interest on some loans while students were enrolled in school, and guaranteed lenders against default. Congress defined interest rates, loan maxima and other loan terms.

During the 1990s, the federal government began offering Stafford loans without a private intermediary through the Direct Loans program. Private lenders continued to offer Stafford loans, side-by-side with the new Direct Loan program. Which program a student borrowed from depended on the college she attended, since colleges opted into Direct Loans.

The participation of the private sector in the federal loan programs was substantially scaled back in 2010. With the passage of the Health Care and Education Reconciliation Act, the Federal Direct Loan Program became the sole source of federal student loans in the United States. The private sector now participates in the Stafford program only as "servicers" for the Department of Education, collecting payments, keeping records and communicating with borrowers.

The shrunken private role in Stafford loans can be traced to two events. First, the financial crisis paralyzed the secondary markets that provided liquidity for private lenders. Short 
of capital, private lenders turned away applicants and delayed loan disbursements, throwing the Stafford program into disarray. The Direct Loan program, whose liquidity relies on the borrowing power of the federal government, was unaffected.

Second, scandals undermined the political capital of the private lenders, who had long campaigned against the expansion of the Direct Loan program. Media coverage depicted private lenders as bribing school officials in order to gain preferential access to their loan-seeking students.

While private lenders no longer offers loans through the federal loan programs, they market a product labeled "student loans.” These private loans comprised as much as ten percent of annual borrowing in the last decade. The private loans differ from the Stafford loans in this crucial dimension: they require a creditworthy borrower or cosigner. As discussed earlier, Stafford loans are provided to students regardless of their creditworthiness and with no security: Stafford loans are "secured" only by the future earnings of the student borrower. By contrast, private student loans are extended only to borrowers who have a good credit record, or a creditworthy consigner. Private student loans are essentially unsecured consumer credit, much like credit cards or personal loans. ${ }^{9}$ Unlike these types of credit, however, private student loans cannot be discharged in bankruptcy.

The terms of private loans are typically worse than on federal loans. For example, these loans do not allow access to the Pay As You Earn program or other initiatives intended to ease

\footnotetext{
${ }^{9}$ Federal PLUS loans, which are made to the parents of college students, also require a minimum level of creditworthiness as defined by the US Department of Education.
} 
repayment, nor so they allow for forbearance. Private loans are particularly prevalent at for-profit colleges, whose students are three times as likely as other undergraduates to hold private loans. ${ }^{10}$

The public-private partnership in the provision of student loans is sometimes strained. During the Great Recession, defaults on student loans spiked. The federal government introduced a variety of repayment plans intended to reduce defaults, but relied on the private servicers to move borrowers into these more forgiving payment plans. Borrowers trickled slowly into the new plans, frustrating policymakers eager to reduce defaults. The Consumer Finance Protection Bureau has documented that in many cases loan servicers are unresponsive to borrowers who want to restructure their payments. ${ }^{11}$ This dynamic echoes that of the mortgage crisis, when the Home Affordable Modification Program (HAMP) was launched to help borrowers struggling with their mortgages. HAMP relied on mortgage servicers to move borrowers into the new plans, but progress was slow. While the goal was for four million borrowers to enroll in HAMP, 1.3 million did so. ${ }^{12}$

Here we have a classic "principal-agent” problem, with the agent (the student loan servicers) having little incentive to act in the best interests of the principal (the federal

\footnotetext{
${ }^{10}$ This begs the question: why would anyone take out a private loan? One hypothesis is that demand is induced by schools that are trying to avoid sanctions from the federal government, which kicks out of the federal aid programs (including the Pell) any schools whose students default too frequently on their federal loans. Some of these schools (community colleges, in particular) have withdrawn altogether from the federal loan program, so that their students have no alternative to the private market. Other schools still formally participate in the federal program, but may steer borrowers they perceive as poor risks toward the private loans rather than the public options. Another, related hypothesis is that students are poorly informed about their borrowing options.

${ }^{11}$ http://files.consumerfinance.gov/f/201310_cfpb_student-loan-ombudsman-annual-report.pdf

${ }^{12} \mathrm{http}: / /$ www.treasury.gov/initiatives/financialstability/reports/Documents/March\%202014\%20MHA\%20Report\%20Final.pdf
} 
government). Student loan servicers don’t have much incentive to prevent borrowers from defaulting, because the servicers either don't own the underlying loans or, if they do, face few costs if a borrower defaults. Restructuring a borrower's payments and preventing default requires effort, and the beneficiary of this effort is the government and the student - not the servicer. Carefully written contracts are required to make such relationships work well; an entire field of economics, mechanism design, is devoted to studying these contracts. In some cases, if the principal cannot get the incentives right, she should just do the job herself. In the present context, that would mean the federal government collecting payments on the loans it makes.

\section{Is There a Student Debt Crisis?}

Student loan debt is lower than is widely perceived. Consider students who first enrolled in college in 2003-04. Six years later, in 2009, 44 percent had borrowed nothing and another 25 percent had borrowed $\$ 10,000$ or less (see Figure 4). That is, 69 percent of undergraduates borrowed $\$ 10,000$ or less. Another 29 percent had borrowed between $\$ 10,001$ and $\$ 50,000$. Only 2 percent had borrowed $\$ 50,001$ or more. Based on limited data, today’s entering college students appear to be on a similar path. While attention is focused on extreme cases, only a very small share of undergraduate borrowers hold the $\$ 100,000$ loans that dominate the headlines. Using the Survey of Consumer Finances, a household survey, Akers and Chingos (2014) reach a similar solution.

\section{Figure 4: Total Borrowing Among Undergraduates First Entering College in 2003-04}




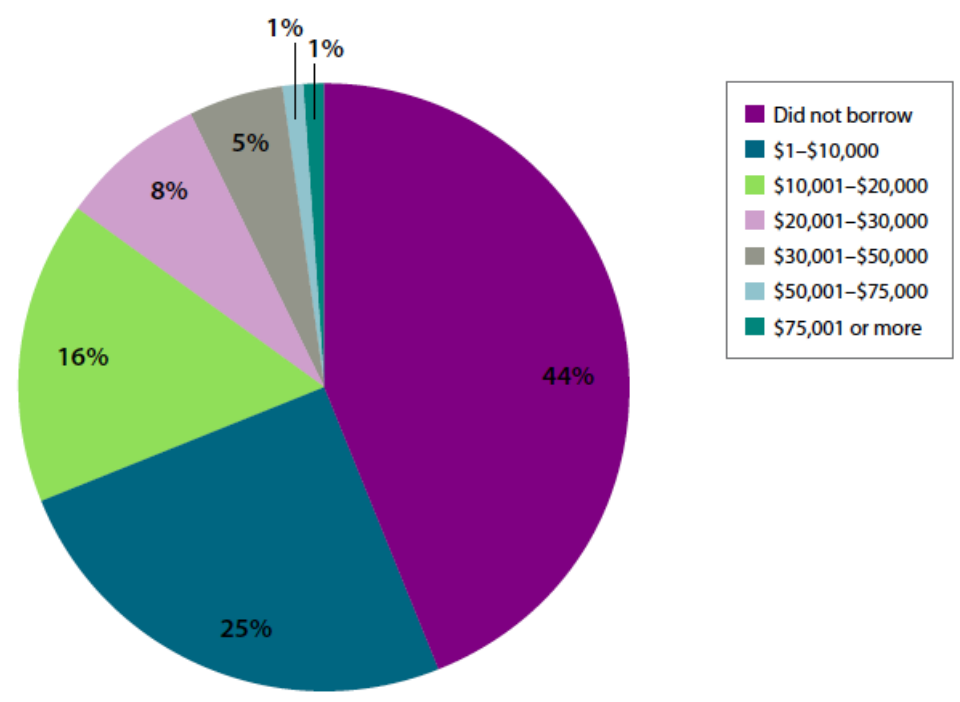

Source: College Board (2012), based on data from the National Postsecondary Student Aid Survey. Borrowing is measured for the six years following first-time college entry.

While attention is focused on borrowers with high loan balances, most defaults occur on much smaller loans. For a cohort of undergraduates who borrowed in 2005, the loan balance of those in default was smaller than among those who paid without adverse event: \$6,625 versus $\$ 8,500 .{ }^{13}$ Looking to the entire loan portfolio, including graduate students, the average loan in default is about $\$ 14,000$, while the average loan not in default is $\$ 22,000 .{ }^{14}$ Furthermore, the data indicate that more students experience temporary rough patches than default, but do not default: the delinquency rate (being behind on payments for 60 to 120 days) is much higher than

\footnotetext{
${ }^{13}$ See Table A-6 in Institute for Higher Education Policy (2011). These numbers are based on a cohort of 1.7 million students who borrowed in 2005. The federal government does not make these statistics available. The authors of the cited study gathered data themselves from loan servicers.

${ }^{14}$ Calculated from data in http://studentaid.ed.gov/sites/default/files/fsawg/datacenter/library/PortfoliobyLoanStatus.xls. There are 6.5 million borrowers in default as of the third quarter of 2013, representing $\$ 89.3$ billion in loans.
} 
the default rate. Most of these delinquent borrowers eventually manage to repay, but with damaged credit histories.

Graduate students borrow more than undergraduates. In fact, much of the recent growth in student debt is attributable to graduate borrowing. In recent years, 40 percent of federal loan dollars were disbursed to graduate students. ${ }^{15}$ Even though graduate students' loan balances are much higher, their default rate is only 3 percent, compared to 21 percent among undergraduate borrowers.

\section{The Costs and Benefits of Interest Rate Subsidies}

Student loans correct a capital market failure: the private sector will not provide loans that are secured only by a borrower's future earnings. If enhanced liquidity were the only goal, loans would be offered at a market rate, with interest capitalized into principal while the student was in college. In the policy arena, it is frequently argued that low interest rates help students by encouraging college attendance and making loan payments more manageable. While an interest subsidy certainly reduces payments (which begin after students leave college), it is a blunt tool for increasing schooling and reducing loan defaults.

In the federal loan program, the interest rate is set to zero during college for low-income students; loans with this benefit are called "subsidized" loans. Assume for the moment that loans are offered at the market rate, and so the in-school payment of interest is the only subsidy. If a student borrows $\$ 1,000$ in her freshman year at a real rate of four percent, spends four years in

\footnotetext{
${ }^{15}$ These figures are from Delisle (2014) and are based on calculations from the National Postsecondary Student Aid Survey.
} 
college, and pays the loan off in ten years, the in-school subsidy saves her \$200 over the life of the loan, or 20 percent of its face value.

All borrowers pay interest on federal loans after leaving school. This interest rate is set by Congress, varies across the federal loan programs and is a hot topic of debate. At times the rate has been fixed in nominal terms, and generated large subsidies for borrowers. During the late 1970s and early 1980s, when interest rates on mortgages were in the double digits, the interest rate on student loans was fixed at eight percent. As of today, interest rates on federal student loans are tied to Treasury bills. The 2013 Student Loan Certainty Act links interest rates to the Federal 10-year Treasury rate, plus a margin. For the 2013-14 academic year, interest rates were 3.86 percent for undergraduate Stafford loans and 5.41 percent for graduate loans. ${ }^{16}$ They are 80 basis points higher for the upcoming academic year. Note that rates do not float for a given loan - rather, they differ by the year in which they loan is initiated but are then fixed over the life of a loan.

Can subsidized interest rates increase college enrollment? A lower interest rate reduces the lifetime costs of college, so a rational decision-maker would include this price subsidy in a calculation of the lifetime, present-discounted value of schooling. However, the evidence from behavioral economics suggests that tangible and salient incentives at the moment of decisionmaking are most effective in changing behavior. ${ }^{17}$ Interest-rate subsidies are not tangible when students are deciding whether to enroll in college: students are handed the same funds whether the loan's interest rate is two percent, four percent or ten percent. The salience of an interest

\footnotetext{
${ }^{16}$ http://www.staffordloan.com/stafford-loan-info/interest-rates.php

${ }^{17}$ Dynarski and Scott-Clayton (2013) discuss this evidence.
} 
subsidy is an unsettled question; I know of no empirical study that estimates a causal relationship between college enrollment and the interest rate charged on student loans. While a field experiment would be most relevant for policy, even a lab experiment would reduce our ignorance about how interest rates affect student decisions.

Can subsidized interest rates reduce loan defaults? Here the answer is more straightforward. In a mortgage-style payment system, where payments are fixed at the beginning of the payment period, a lower interest rate reduces the monthly payments required to cover principal and interest. In this case, a lower interest rate will make loan payments more manageable for marginal borrowers and thereby reduce defaults. However, an across-the-board interest subsidy benefits every borrower, including those who have high earnings and no difficulty repaying loans. An interest subsidy is therefore a poorly targeted (and expensive) tool for reducing loan default in a mortgage-style repayment system. Tying payments to income, as discussed in Section VII, is a more targeted mechanism for reducing default.

In an income-based repayment system (discussed in Section VII) payments are a fixed percentage of income. The interest rate does not enter into the calculation of the monthly payment and affects only the length of repayment. For a borrower with a given principal and lifetime income, a lower rate will reduce the time required to pay off the loan. This subsidy therefore arrives at the end of the repayment period: payments stop earlier than they would have otherwise. In a twenty-year repayment plan, this would means that a borrower stops making payments (for example) when she is 42 rather that at age 43 . These are peak earning years, and the risk of default in this period is likely to be relatively low; the effect of the subsidy on reducing defaults is also likely to be low. Further, this early cessation of payments equally benefits borrowers with very high incomes and those with typical incomes. An interest subsidy is 
therefore a poorly targeted (and expensive) tool for reducing loan default in an income-based repayment system.

\section{Income-Based Repayment Plans Align the Timing of the Costs and Benefits of College}

A college education is an investment that pays off over many decades. Over a lifetime, the typical college graduate earns several hundred thousand dollars more than a high school graduate. For most types of borrowing, the life of a loan matches the life of the collateral. However, under the current system, the standard repayment period for a student loan is ten years. The mismatch between the timing of the costs and benefits of education is especially salient among young borrowers, who are most likely to default. Among borrowers under 21, for example, 28 percent default on their loan. The default rate drops sharply with age, to 18 percent of those thirty to forty-four and 12 percent among those forty-five and older (Institute for Higher Education Policy, 2011). This pattern of defaults matches the age profile of earnings. Earnings are lowest in the years right after college, when borrowers pay their loans. Among those with at least a BA, median earnings are $\$ 32,000$ for those aged twenty-four to thirty, $\$ 48,000$ for those thirty-one to forty, and $\$ 50,000$ among those forty-one through forty-eight. ${ }^{18}$

An income-based repayment system determines loan payments based on income.

Payments rise and fall with income, thereby reducing pressure on borrowers when they first

\footnotetext{
18 These statistics are from the 2012 March Current Population Survey (authors' calculations) exclude full-time students but include former students who are out of the labor force or unemployed. The twenty-fifth percentiles for those with a BA are $\$ 14,000, \$ 24,000$, and $\$ 15,000$, respectively. Among those with some college but no BA, median earnings are $\$ 24,000$ for those aged twenty-four to thirty, $\$ 30,000$ for those in their thirties, and $\$ 34,000$ for those aged forty-one to forty-eight. The twenty-fifth percentiles for this group are $\$ 6,000, \$ 15,000$, and $\$ 12,000$, respectively.
} 
graduate college (and whenever earnings are low). There are income-based loan programs in Australia, Chile, New Zealand, Thailand, and the United Kingdom. In the United Kingdom, for instance, borrowers contribute 9 percent of any income that exceeds $£ 21,000$; any remaining student-loan balance is forgiven after thirty years. These countries can be useful models as policymakers explore switching to an income-based repayment schedule. Dynarski and Kreisman (2013) describe one such model for the United States.

Policymakers can adjust the specific parameters of an income-based system to achieve alternative goals. Indeed, there are many contribution schedules that will work, with the choices affecting the length of payment, the level of payments, and the share of loans forgiven. A lower contribution rate leads to a lower payment, a longer payment horizon, more interest paid by the borrower, and more loans forgiven after twenty-five years. Higher contribution rates have the opposite effects.

The Pay As You Earn program (PAYE), which Mr. Obama expanded in his June order, theoretically holds payments to 10 percent of income. The key limitations of PAYE, as well as all of the other income-based repayment plans in the US, are that they are not the default option and payments don’t adjust automatically with earnings.

The default option for borrowers is a ten-year, mortgage-style, fixed payment. Borrowers must proactively apply to the income-based programs and demonstrate financial distress before being admitted. Eligibility must be renewed annually. As the theory and evidence of behavioral economics has demonstrated, defaults matter and even small administrative hurdles can keep people from making beneficial choices. The Consumer Financial Protection Bureau has 
documented the difficulties that borrowers have in navigating this process. ${ }^{19}$ The number of borrowers in these flexible repayment plans is much lower than the number in distress and default, which is evidence that the current system isn’t working to insure borrowers against risk

Payments do not adjust automatically in the existing income-based payment programs.

They are based on the previous year's income, and change only if the borrower submits evidence that income has changed. This backward-looking approach does not deal with shocks to income as they arrive. As a result, even a borrower enrolled in PAYE can see more than ten percent of income consumed by loan payments, if her earnings drop while enrolled in the program. Or less than ten percent of her income may go to payments, if her earnings rise.

To effectively buffer earnings shocks as they arrive, payments need to adjust dynamically with earnings. Such a framework has been advanced by several policy organizations, as well as legislation currently pending in the US Senate. ${ }^{20}$ How would such a system work in the United States? Social Security is a good model. Workers in the US do little paperwork to make Social Security contributions: they complete an initial W-4 form and the employer handles the rest. Social Security contributions then automatically rise and fall with earnings. Loan payments can be handled the same way.

Some states are already moving toward income-based repayment. Michigan has now joined Oregon in proposing a "Pay It Forward" student lending system in which students pay no tuition up front and pay back a fixed percentage of their income after college. This sounds very similar to the income-based repayment system I describe above. However, a key distinction is that in a Pay It Forward program a borrower contributes a fixed percentage of income for a fixed

\footnotetext{
${ }^{19}$ http://files.consumerfinance.gov/f/201310_cfpb_student-loan-ombudsman-annual-report.pdf

${ }^{20}$ See Dynarski (2014) for a discussion of these proposals.
} 
number of years. The liability is not denominated in dollars, as in a standard loan, but as a fixed number of payments. Economists call this a graduate tax -a tax on earnings for those who have gone to college. It is called a tax, rather than a payment, because a borrower can't buy her way out of the liability. The borrower is taxed for 25 years, even if she has repaid the principal (plus interest) after a few years.

In the proposed Pay It Forward systems, a graduate who does extremely well in the labor market will end up repaying many times over the cost of her education, while one who does poorly will pay much less. There is therefore cross-subsidization in this system, with the "winners" paying some of the college costs of the "losers." Economic theory suggests that loans funded by a graduate tax won’t work because those expecting high earnings won’t participate. This is a classic case of adverse selection - borrowers who would be subsidized participate while those who would subsidize stay away. This is unsustainable, as without the high earners the system does not get enough payments to cover tuition costs. Because of adverse selection graduate tax can work only if participation is mandatory, with everyone forced into the borrowing pool.

This is similar to the dynamic in insurance markets, which collapse if sick people buy coverage and healthy ones go without. The young, healthy participants cross-subsidize the older, sicker participants, just as high earners subsidize low earners in a (mandatory) graduate tax. Neither the Oregon nor Michigan plan requires all borrowers to participate in their programs. This suggests that the programs would be brought down by adverse selection. ${ }^{21}$

\footnotetext{
${ }^{21}$ Yale attempted a graduate tax in the 1970s, lending money to its undergraduates and then having them pay back a fixed percentage of their income for a fixed number of years. The program collapsed, with Yale ultimately forgiving outstanding debt.
} 
A minor change to Pay It Forward will maintain its positives (simplicity, insurance against bad draws in the labor market) while eliminating the negative (unsustainability caused by adverse selection). The change is this: denominate debt in dollars, and let borrowers pay off their debt. If a student borrows $\$ 25,000$ and earns enough that she has paid back the principal plus interest after just ten years, she will stop paying into the program. If a borrower instead runs into hard times and still owes money after 25 years, the balance is forgiven.

\section{Data on Student Loans Are Incomplete}

An evidence-based policy requires data. Data on student loans are remarkably thin, given the size of this market. They are particularly inadequate for modeling and costing out incomebased repayment plans. Understanding the relationship between individual earnings and borrowing is critical for designing sound loan policy. If many former students carry debt beyond their capacity to repay, policymakers need to reconsider the parameters of student borrowing, such as eligibility, loan limits, loan forgiveness, and repayment structures. All of these topics are currently under discussion in Washington, with little data to inform the debate.

To calculate the costs of an income-based repayment program, which typically includes a forgiveness provision after a certain number of years, we need to know about borrowers' lifetime earnings. Many data sources contain information on lifetime earnings. There are also comprehensive administrative data on borrowing through the federal loan programs. The two have not been linked, however, which leaves analysts unable to examine the covariance between lifetime earnings and borrowing. This is a critical parameter for designing a sustainable incomebased repayment system. 
An example will demonstrate the necessity of individual-level data on earnings and borrowing. The default rate on small loans is higher than that on large loans: the average loan in default is $\$ 14,000$ while the average loan in good standing is $\$ 22,000 .^{22}$ This pattern of defaults is consistent with two scenarios with very different implications for policy.

One scenario is that defaulters have temporarily low earnings and their loans fall into distress during these unusual bad times. At low cost to government, an income-based repayment program would insure borrowers against these temporary downturns by automatically reducing their payments. If lifetime earnings are sufficient to pay off the loans, this system can be selffunding.

An alternative scenario is that those who default have permanently low earnings that cannot support even moderate debt loads. An income-based repayment plan would still help these borrowers, but the ultimate cost to government would be much higher, since many of these loans will ultimately be forgiven. The cost of making, servicing and forgiving these loans could be so high that a grant program could be cheaper for taxpayers.

Distinguishing between these two scenarios requires individual-level, longitudinal data on student borrowing and earnings that follows former students for twenty-five years after college. Why twenty-five years? Income-based repayment plans have students paying back their loans 20 to 25 years, when any remaining balance is forgiven. Costing out these programs therefore requires tracking earnings for decades. Why individual-level, longitudinal data? Individual-level data are needed to capture the shocks to income that income-based repayment

${ }^{22}$ Calculated from data in spreadsheet "Direct Loan and Federal Family Education Loan Portfolio by Loan Status,” accessed October 2013. http://studentaid.ed.gov/sites/default/files/fsawg/datacenter/library/PortfoliobyLoanStatus.xls 
programs insure against. The payments required of borrowers with different earnings paths cannot be backed out from group averages. Any analysis that relies on averages will smooth away the within-person shocks that are needed to estimate the benefits and costs of income-based repayment.

How could this gap in the data be filled? The longitudinal surveys fielded by the US Department of Education's National Center for Educational Statistics (NCES) contain partial information on borrowing and earnings. They would be adequate for the task of guiding loan policy were they supplemented with administrative data.

The decadal NCES cohort surveys, which follow a high school class every ten years, follow respondents only to early adulthood, typically stopping when respondents are in their twenties. ${ }^{23}$ The postsecondary surveys (fielded about every five years) stop following respondents about ten years after the start of college. ${ }^{24}$

To extend the borrowing data available for these surveys, they could be linked to the National Student Loan Data System (NSLDS), an administrative data set that contains all federal

\footnotetext{
${ }^{23}$ The National Longitudinal Survey of the High School Class of 1972 surveyed students until 1986, when they were about 32. High School and Beyond, which includes the high school class of 1982, stopped surveying students when they were in their twenties (in 1986, four years after high school). So did the National Education Longitudinal Study of 1988, which stopped surveying in 2000 (when respondents were about eight years out high school). The surveys currently in the field (Education Longitudinal Study of 2002 and the High School Longitudinal Study of 2009) are not planned to survey any later in life than their predecessors. See http://nces.ed.gov/surveys/hsb.

${ }^{24}$ The Baccalaureate and Beyond has varied in how long it tracks students. Graduates who started college in 1993 were followed for ten years, which would yield a typical exit age of late twenties. See http://nces.ed.gov/surveys/b\&b/about.asp.
} 
student loans. These links would be updated annually; they are currently updated only a couple of times during the life of the surveys.

To extend the earnings data available for these samples, they could be linked to administrative data from the Social Security Administration (SSA) or Internal Revenue Service (IRS):

- SSA maintains longitudinal records of individual earnings. These records are used to compute Social Security benefits, which, like income-based student-loan repayments, are a function of lifetime earnings. Researchers have successfully linked SSA data to surveys, including the Census (an example is Angrist, Chen, and Song, 2011).

- IRS maintains household-level records of income-tax returns and the informational returns that are used in the calculation of taxes. These data include information on college attendance, in the form of the 1098-T, which colleges send to the IRS to document tuition payments. In recent years, versions of these data have become available to outside researchers (e.g., Chetty et al., 2011). Treasury employees can also conduct research with these data, and outside researchers have coauthored with them on studies (e.g., Manoli and Turner, 2014).

The merged versions of these surveys with administrative data would, by necessity, contain detailed, individual-level data from multiple government agencies. There are legal, political and administrative barriers to creating and releasing such sensitive data, but they can be overcome. The Census Bureau has been particularly aggressive and creative in matching administrative data to its surveys and finding new ways to distribute those data to researchers, and could provide a model for these purposes.

Census has linked its Survey of Income and Program Participation (SIPP) to data from the Internal Revenue Service and made it available in its secure Research Data Centers, which are located across the country and open to researchers who have undergone an extensive vetting process. The downside of this model is that a very limited number of researchers gain access to 
the data. A more promising approach is that taken by the SIPP Synthetic Beta. ${ }^{25}$ Through this pilot project, Census publicly releases a version of its SIPP-SSA-IRS match that is "perturbed," with some variables statistically blurred to prevent identification. An unperturbed version of the matched data sits on the Census servers. Researchers run and refine their statistical models on the publicly available data, on their own computers. They can then upload the resulting code to the Census servers, where it is run on the original, unperturbed data. Results are returned to the researcher after being checked for compliance with data standards (e.g., minimum cell sizes).

The SIPP Synthetic Beta is a promising model for NCES to distribute versions of its data that include variables sufficiently detailed that they threaten to reveal individual identities. This model could be used as the standard for merges of NCES surveys with sensitive data from IRS and SSA. Agencies reluctant to allow their data to be released to researchers may well cooperate when the SIPP Synthetic model is used, with public versions being statistically perturbed. This approach appears to have worked with IRS and SSA, agencies that are notoriously protective of their data.

\section{Conclusion}

In this paper, I provide an economic perspective on student debt in the United States. Governments across the world provide student loans, allowing students to borrow against the lifetime welfare gains created by a college education. While borrowing has risen over time in the US, so too has the return to schooling. The typical student holds debt that is well below the

\footnotetext{
${ }^{25}$ See http://www.census.gov/programs-surveys/sipp/methodology/sipp-synthetic-beta-dataproduct.html for more information.
} 
lifetime benefits of a college education. The typical student borrower is not "under water," as were many homeowners during the mortgage crisis.

Rather, there is a mismatch in the timing of the arrival of the benefits of college and its costs, with payments due when earnings are lowest and most variable. Ironically, this mismatch is the very motivation for providing student loans in the first place. One solution is an incomebased-repayment structure for student loans, with payments automatically flexing with earnings over a longer horizon than the ten years that is currently standard.

There are income-based repayment options in the US, but the administrative barriers to accessing them are considerable. Further, the existing options do not adjust loan payments quickly enough to respond to the high-frequency shocks that characterize young people's earnings, especially during a recession.

A well-structured repayment program would insure borrowers against both micro and macro shocks. With an interest rate that appropriately accounts for the government's borrowing and administrative costs, as well as default risk, this program could be self-sustaining. Designing such a program requires detailed data on individual earnings and borrowing, which are currently unavailable to researchers within and outside the government. If loan policy is to be firmly grounded in research, this gap in the data must be closed.

\section{References}

Akers, Beth, and Matthew Chingos. 2014. “Is a Student Loan Crisis on the Horizon?” Brown Center on Education Policy, Brookings Institution.

Angrist, Joshua D., Stacey Chen and Jae Song. 2011. "Long-Term Consequences of VietnamEra Conscription: New Estimates Using Social Security Data.” American Economic Review 101(3): 334-38. 
Chetty, Raj, John Friedman, Nathaniel Hilger, Emmanuel Saez, Diane Whitmore-Schanzenbach, and Danny Yagan. 2011. "How does your Kindergarten Classroom affect your Earnings? Evidence from Project Star.” The Quarterly Journal of Economics Vol. CXXVI November 2011, Issue 4.

College Board (2012). Trends in Student Aid 2012. http://trends.collegeboard.org/sites/default/files/student-aid-2012-full-report-130201.pdf

College Board (2013). Trends in Student Aid 2013. http://trends.collegeboard.org/sites/default/files/student-aid-2013-full-report.pdf

Delisle, Jason (2014). The Graduate Student Debt Review. Unpublished manuscript, New America Foundation. http://newamerica.net/sites/newamerica.net/files/policydocs/GradStudentDebtReviewDelisle-Final.pdf

Dynarski, Susan (2014). “Finding Shock Absorbers for Student Debt.” June 15, 2014. New York Times, p. BU8.

Dynarski, Susan and Daniel Kreisman. 2013. "Loans for Educational Opportunity: Making Borrowing Work for Today’s Students.” The Hamilton Project. http://www.brookings.edu/research/papers/2013/10/21-student-loans-dynarski

Dynarski, Susan and Judith Scott-Clayton, (2013). "Financial aid policy: lessons from research.” Future of Children, 23(1), 67-91.

Field, E. (2009). "Educational debt burden and career choice: evidence from a financial aid experiment at NYU Law School.” American Economic Journal: Applied Economics, $1(1), 1-21$.

Gurgand, M., Lorenceau, A., \& Mélonio, T. (2011). "Student loans: liquidity constraint and higher education in South Africa.” Agence Française de Développement Working Paper No. 117. Retrieved from http://papers.ssrn.com/sol3/papers.cfm?abstract_id=1969424.

Institute for Higher Education Policy (2011). Delinquency: the Untold Story of Student Loan Borrowing.

Lee, Donghoon. (2013). "Household Debt and Credit: Student Debt.” Federal Reserve Bank of New York. http://www.newyorkfed.org/newsevents/mediaadvisory/2013/Lee022813.pdf

Manoli, Dayanand S. and Turner, Nicholas. 2014. "Cash-on-Hand and College Enrollment: Evidence from Population Tax Data and Policy Nonlinearities.” NBER Working Paper 19836.

Piketty, Thomas, and Emmanuel Saez. 2003. "Income Inequality in the United States, 19131998.” Quarterly Journal of Economics 118 (1), 2003, 1-39. 
Solis, Alex (2012). Credit access and college enrollment (Uppsala University Department of Economics Working Paper No. 2013:12). Retrieved from http://alexsolis.webs.com/CreditAccessSolis_v3.pdf.

US Department of Education (2012). Digest of Education Statistics. http://nces.ed.gov/pubs2014/2014015.pdf 